\title{
ANALISIS KEMAMAMPUAN KOMUNIKASI SISWA MENENGAH TERHADAP RESILIENSI MATEMATIS
}

\author{
Citra Rahmawati ${ }^{1}$, Luvy Sylviana Zhanty ${ }^{2}$ \\ 1,2 IKIP Siliwangi Bandung, \\ ${ }^{1}$ citrar27@gmail.com,2.2 Lszhanty@gmail.com.
}

Diterima: 3 Februari 2019; Disetujui: 31 Mei 2019

\begin{abstract}
The purposes of this study are to identify the level of communication skills and mathematical resilience of junior high school students and to find out their mistakes in finishing communicationbased questions. The method used in this study is descriptive quantitative method. This study is conducted in an Islamic school namely MTs Al Basyariyah located in Bandung, Indonesia. Performing as the respondents of this study are 36 students of class IX-B. To collect the data, this study employs a communication-based question diagnostic test and a questionnaire on student resilience. The results of the study show that (1) most of the students find it difficult to do question number one whose indicator is written text; (2) students' skill on doing communication-based questions is still low; and (3) there is not significant correlation between students' communication skills and their resilience. To cope with these phenomena, it is recommended that teachers use learning strategies that are able to enhance students' conceptual understanding so that their communication skills can be achieved.
\end{abstract}

Keywords: Communication Skills, Mathematical Resilience

\begin{abstract}
Abstrak
Tujuan penelitian ini untuk mengetahui tingkat kemampuan komunikasi dan resiliesi matematis siswa SMP serta untuk mengetahui kesalahan siswa dalam menyelesaikan soal berkemampuan komunikasi. Metode penelitian ini adalah deskriftif kuantitatif. Tempat penelitian dilaksanakan di MTs Al Basyariyah Bandung dengan subjek penelitian kelas XI-B yang berjumlah 36 orang. Untuk memperoleh data penelitian digunakan instrument tes diagnostik soal kemampuan komunikasi dan angket resiliensi siswa. Hasil penelitian menunjukan bahwa : (1) kebanyakan siswa mengalami kesulitan dalam mengerjakan soal nomor satu dengan kemampuan written text ; (2) tingkat kemampuan siswa pada soal komunikasi sangat rendah; (3) tidak terdapat hubungan yang signifikan antara kemampuan komunikasi dan resiliensi siswa. Adapun solusi untuk mengatasi hambatan tersebut hendaknya guru menggunakan strategi pembelajaran yang dapat meningkatkan pemahaman konsep siswa, sehingga kemampuan komunikasi siswa dapat tercapai.
\end{abstract}

Kata Kunci: Kemamapuan Komunikasi, Resiliensi Matematis

How to cite: Rahmawati, C., Zhanty, L. S., (2019). Analisis Kemamampuan Komunikasi Siswa Menengah Terhadap Resiliensi Matematis. JPMI - Jurnal Pembelajaran Matematika Inovatif, 2 (3), 147-154.

\section{PENDAHULUAN}

NCTM memaparkan standar kemampuan matematis yang harus dimiliki oleh siswa ada lima yaitu: Problem Solving (pemecahan masalah), Reasoning and Proof (penalaran dan pembuktian), Connection (mengaitkan ide-ide matematika), Communication (komunikasi 
matematika), dan Representation (representasi). Hal ini sejalan dengan salah satu standar kompetensi lulusan untuk mata pelajaran matematika adalah mengkomunikasikan gagasan dengan simbol, tabel, diagram atau media lainnya untuk membantu memperjelas suatu masalah (Departemen Pendidikan Nasional, 2007).Berdasarkan pernyataan tersebut, kemampuan komunikasi merupakan salah satu komponen penting dalam pengembangan berpikir siswa. Menurut (Umar, 2012) ada dua alasan penting matematika terfokus pada pengkomunikasian. Pertama, matematika adalah bahasa. Kedua, matematika merupakan aktivitas sosial. Nopiyani, Turmudi, \& Prabawanto, (2018) juga mengatakan bahwa perlunya kemampuan komunikasi yaitu untuk lebih memaknai bahwa matematika bukan sekedar simbol tanpa makna melainkan matematika itu adalah bahasa yang berguna untuk membantu penyelesaian masalah dalam kegiatan setiap hari.

Indikator kemampuan komunikasi yang dikemukakan oleh Kementrian Ontario tahun 2005 (Hendriana, Eti Rohaeti, \& Soemarmo, 2017) adalah : (1) Writen text, yaitu memberikan jawaban dengan gaya bahasa sendiri; (2) Drawing, yaitu merefleksikan benda nyata, gambar, atau diagram ke dalam matematika; (3) Mathematical expressions, yaitu mengungkapkan konsep matematika dengan menyatakannya ke dalam kehidupan sehari-hari atau terhadap simbol matematika. Maka dari itu peneliti mengambil indikator tersebut untuk mengetahui seberapa tingginya tingkat kemampuan komunikasi siswa.

Guru tidak hanya membantu siswa dalam menanggulangi kesulitan untuk tercapainya kemampuan matematik, melainkan seorang guru harus berusaha mengembangkan sikap positif terhadap matematika. Sikap yang dimaksud seperti kemandirian belajar (self regulated learning), percaya diri (self confidence), kemampuan diri (self efficacy), skala konsep diri (self concept), dan rasa tekun dan tangguh dalam menghadapi kesulitan belajar matematika.

Johnston-Wilder \& Lee menamai sikap tetap tangguh dalam situasi sulit itu dengan istilah resiliensi matematis (Mathematical Resilience). Sumarmo mengemukakan bahwa JohnstonWilder dan Lee mengatakan bahwa resiliensi memiliki empat faktor yaitu : (a) meyakini bahwa kemampuan otak dapat ditumbuhkan; (b) pemahaman personal terhadap nilai-nilai matematika; (c) bagimana cara bekerja dalam matematika; (d) kesadaran terhadap dukungan teman, internet, ICT, dan lainnya (Maryam, Nurdiawan, Hermawan, Purwasih, \& Rohaeti, 2018)

Dalam kegiatan pembelajaran, rasa teguh dalam situasi sulit haruslah dimiliki oleh siswa, hal ini bertujuan untuk merubah seseorang dari keterpurukan atau kesengsaraan dalam hidup, karena tidak ada satupun makhluk hidup di dunia tanpa suatu kesulitan dan masalah (Zanthy, 2018). Hal ini sesuai dengan pengalaman penulis ketika melaksanakan kegiatan Magang III. Saat siswa mengerjakan soal yang sulit, siswa melampiasakan dirinya kepada perilaku yang negatif. Contohnya, menyontek, mengobrol, ataupun tidur. Perilaku seperti ini haruslah dirubah dan mengarahkannya kepada perilaku positif. Sifat positif seperti kemampuan resiliensi akan mendorong siswa untuk bisa tangguh dalam situasi sulit jika siswa memiliki kemampuan resiliensi yang tinggi. Namun, sebaliknya jika siswa berkemampuan resiliensi rendah maka dirinya akan kehilangan sikap teguh atau menyerah atau tidak percaya diri dalam situasi sulit. Hal ini dapat disimpulkan bahwa kemampuan resiliensi siswa memberikan respon yang positif terhadap pembelajaran matematika. Maka dari itu, peneliti mencoba mengukur sejauh mana hubungan kemampuan komunikasi terhadap resiliensi matematis. 


\section{METODE}

Pengumpulan data ini menggunakan pendekatan kualitatif dengan metode deskriftif. Mulyadi (Mulyadi, 2011) mengemukakan bahwa penelitian deskriftif bertujuan untuk menggambarkan variabel yang berkenaan dengan masalah yang diteliti dengan menghubungkan gejala kenyataan sosial yang terjadi. Sementara itu, menurut (Bachri, 2010) mengatakan bahwa metode penelitian kualitatif ditujukan untuk menganalisis peristiwa secara individual atau kelompok dalam penemuan prinsip-prinsip yang mengarah pada penarikan kesimpulan. Tujuan peneltian ini untuk menggambarkan tentang kesalahan siswa dalam menyelesaikan soal-soal komunikasi dan hubungannya dengan kemampuan resiliensi matematis siswa. Subjek penelitian ini adalah siswa kelas IX pada semester ganjil di MTs Al- Basyariyah Cigondewah Kabupaten Bandung yang berjumlah 36 orang. Langkah-langkah penelitian ini melalui tiga tahap yaitu: (1) Persiapan, yaitu mengkaji permasalahan, menyusun latar belakang dan landasan teori, mempersiapkan instrumen penelitian, mengurus perizinan, dan menentukan jadwal penelitian; (2) Pelaksanaan, yaitu memberikan tes kemampuan komunikasi, dan dilanjut dengan mengisi angket; (3) Evaluasi, yaitu mengumpulkan, mengolah, menganalisis, menyimpulkan data hasil penelitian

Instrumen yang digunakan adalah tes dan non tes. Instrument tes digunakan untuk mengetahui sejauh mana kemampuan komunikasi siswa. Instrumen tes terdapat tiga soal berkemampuan komunikasi dimana pada setiap soalnya mewakili setiap indikator kemampuan tersebut. Soal tersebut diadopsi dari (Mulyana. A : 2015) dan (Nurzaman, A. : 2016) yang telah diuji dan mempunyai validitas isi dan reliabilitas. Dari hasil tes tersebut kemudian dihitung presentase skor masing-masing soal.

$$
P=\frac{T}{S \times N} \times 100 \%
$$

Keterangan :

P : Presentase skor tiap butir soal

$\mathrm{T}$ : Total skor masing-masing indikator tiap butir soal seluruh objek

$\mathrm{S}$ : Skor maksimum tiap indikator butir soal

$\mathrm{N}$ : Banyak subjek

Setelah menganalisis presentase skor setiap soal secara individu kemudian menganalisis presentase Pencapaian Kemampuan Matematis (PKM) klasikal siswa secara keseluruhan dengan menggunakan rumus :

$$
P K M=\frac{\text { banyak siswa yang memperoleh skor } \geq K K M}{\text { banyak siswa }} \times 100
$$

dengan interval presentase sebagai berikut :

Tabel. 1 Interval PKM Klasikal.

\begin{tabular}{ll}
\hline Interval & Kategori \\
\hline $85-100 \%$ & Sangat Tinggi \\
$75-84 \%$ & Tinggi \\
$60-74 \%$ & Sedang \\
$40-59 \%$ & Rendah \\
$0-39 \%$ & Sangat Rendah \\
\hline
\end{tabular}


Instrument non tes berupa angket resiliensi matematik skala likert termodifikasi. Angket resiliensi matematik dibuat dalam bentuk pernyataan sebanyak 16 pernyataan digunakan untuk mengetahui sejauh mana resiliensi siwa terhadap pembelajaran matematika.

\section{HASIL DAN PEMBAHASAN}

\section{Hasil}

Setelah melakukan tes tulis sebanyak tiga soal berkemampuan komunikasi yang berbentuk uraian, diperoleh hasil penskoran dari hasil jawaban siswa yang disajikan pada tebel 2 .

Tabel 2. Rekapitulasi Hasil Tes Kemampuan Komunikasi

\begin{tabular}{|c|c|c|c|c|c|c|c|c|}
\hline \multirow{3}{*}{ Indikator } & \multirow{3}{*}{$\begin{array}{c}\text { Nomor } \\
\text { Soal }\end{array}$} & \multicolumn{6}{|c|}{ Jawaban } & \multirow{3}{*}{$\begin{array}{c}\text { Presentase } \\
\text { Skor } \\
\text { Siswa } \\
\text { Perbutir } \\
\text { Soal (\%) }\end{array}$} \\
\hline & & \multicolumn{2}{|c|}{ Benar } & \multicolumn{2}{|c|}{ Kurang Tepat } & \multicolumn{2}{|c|}{$\begin{array}{l}\text { Tidak Ada } \\
\text { Jawaban }\end{array}$} & \\
\hline & & $\mathrm{N}$ & $\%$ & $\mathrm{~N}$ & $\%$ & $\mathrm{~N}$ & $\%$ & \\
\hline \multirow{3}{*}{$\begin{array}{l}\text { Written text } \\
\text { Mathematical } \\
\text { expression } \\
\text { Drawing }\end{array}$} & 1 & 0 & 0 & 16 & $44,4 \%$ & 20 & $55,6 \%$ & $27,5 \%$ \\
\hline & 2 & 0 & 0 & 33 & $91,7 \%$ & 3 & $8,3 \%$ & $50 \%$ \\
\hline & 3 & 10 & $27,8 \%$ & 25 & $69,4 \%$ & 1 & $2,8 \%$ & $82,6 \%$ \\
\hline
\end{tabular}

Dari tabel 1 dapat dilihat pada soal nomor satu pada indikator written text tidak terdapat jawaban benar, 44,4 \% siswa menjawab kurang tepat, dan 55,6 \% siswa tidak menjawab. Dari data di atas dapat disimpulkan siswa sangat mengalami kesulitan dalam mengerjakan soal nomor satu. Hasil perhitungan presentase skor seluruh siswa pada soal nomor satu adalah 27,5 $\%$ dengan kualifikasi rendah. Pada soal nomor dua dengan indikator mathematical expression tidak terdapat siswa menjawab dengan benar, 91,7 \% siswa menjawab kurang tepat, dan 8,3 $\%$ siswa tidak menjawab soal. Dari hasil tersebut disimpulkan siswa mempunyai tingkat kecerobohan yang sangat tinggi. Hasil rerata presentase skor seluruh siswa pada soal nomor dua $50 \%$ dengan kualifikasi sedang. Pada soal nomor tiga dengan indikator drawing 27,8 \% jawaban siswa benar, 69,4\% jawaban kurang tepat, dan 2,8 \% siswa tidak menjawab. Dari hasil tersebut dapat disimpulkan bahwa sebagian siswa dapat mengerjakan dengan tingkat kecerobohan rendah. Hasil rata-rata presentase skor seluruh siswa pada soal nomor tiga 82,6 $\%$ dengan kualifikasi tinggi.

Setelah menganalisis hasil pencapaian kemampuan komunikasi secara individu, kemudian didapatkan hasil pencapaian kemampuan komunikasi secara keseluruhan. Terdapat enam orang siswa yang mendapatkan nilai melebihi KKM (65) dengan Skor Maksimum Ideal 32. Nilai presentase PKM yang diperoleh adalah 16,67 \% menunjukan bahwa tidak sampai $85 \%$ siswa memperoleh nilai di atas KKM. Berdasarkan kategori PKM, presentase 16,67 \% tergolong sangat rendah. Dapat disimpulkan bahwa kemampuan konumikasi siswa sangat rendah. 
Tabel 3. Hasil Uji Korelasi

\begin{tabular}{llll}
\hline \multirow{3}{*}{ Kognitif } & & Kognitif & Afektif \\
\cline { 2 - 4 } & Pearson Correlation & 1 & 0,187 \\
\cline { 2 - 4 } & Sig. (2-tailed) & 36 & 0,274 \\
\cline { 2 - 4 } & $\mathrm{N}$ & 36 & 36 \\
\hline Afektif & Pearson Correlation & 0,187 & 1 \\
\cline { 2 - 4 } & Sig. (2-tailed) & 0,274 & 36 \\
\cline { 2 - 4 } & $\mathrm{N}$ & 36 & \\
\hline
\end{tabular}

Dari tabel uji korelasi didapatkan nilai signifikansi adalah 0,247 maka dapat dikatakan bahwa tidak terdapat korelasi dari kemampauan komunikasi dan kemampuan resiliensi matematis siswa. Sama halnya dengan nilai derajat korelasi adalah 0,187 berarti tidak ada korelasi dari kedua kemampuan tersebut.

\section{Pembahasan}

Salah satu jawaban kurang tepat pada soal nomor satu dengan indikator written text disajikan pada gambar 1 .

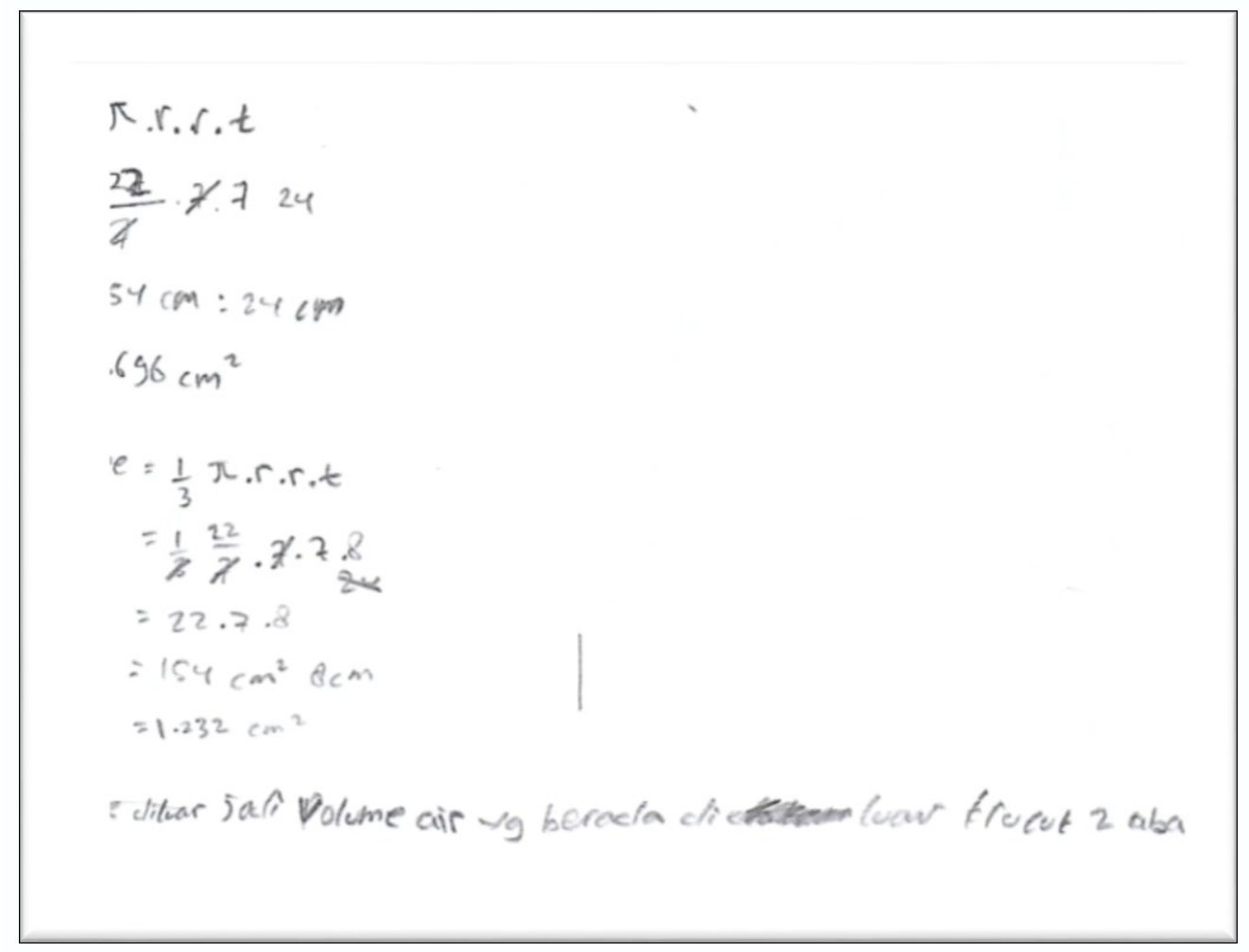

Gambar 1. Hasil pekerjaan siswa pada soal nomor satu.

Berdasarkan gambar 1 terlihat siswa sudah melengkapi data dan membuat proses perhitungan dengan tepat. Akan tetapi siswa tidak bisa menuliskan maksud dari soal tersebut. Sehingga, proses penyelesaian terakhir terlewatkan. 
152 Rahmawati,\& Zhanty, Analisis Kemamampuan Komunikasi Siswa Menengah Terhadap ...

Salah satu jawaban kurang tepat pada soal nomor dua dengan indikator mathematical expression disajikan pada gambar 2 .

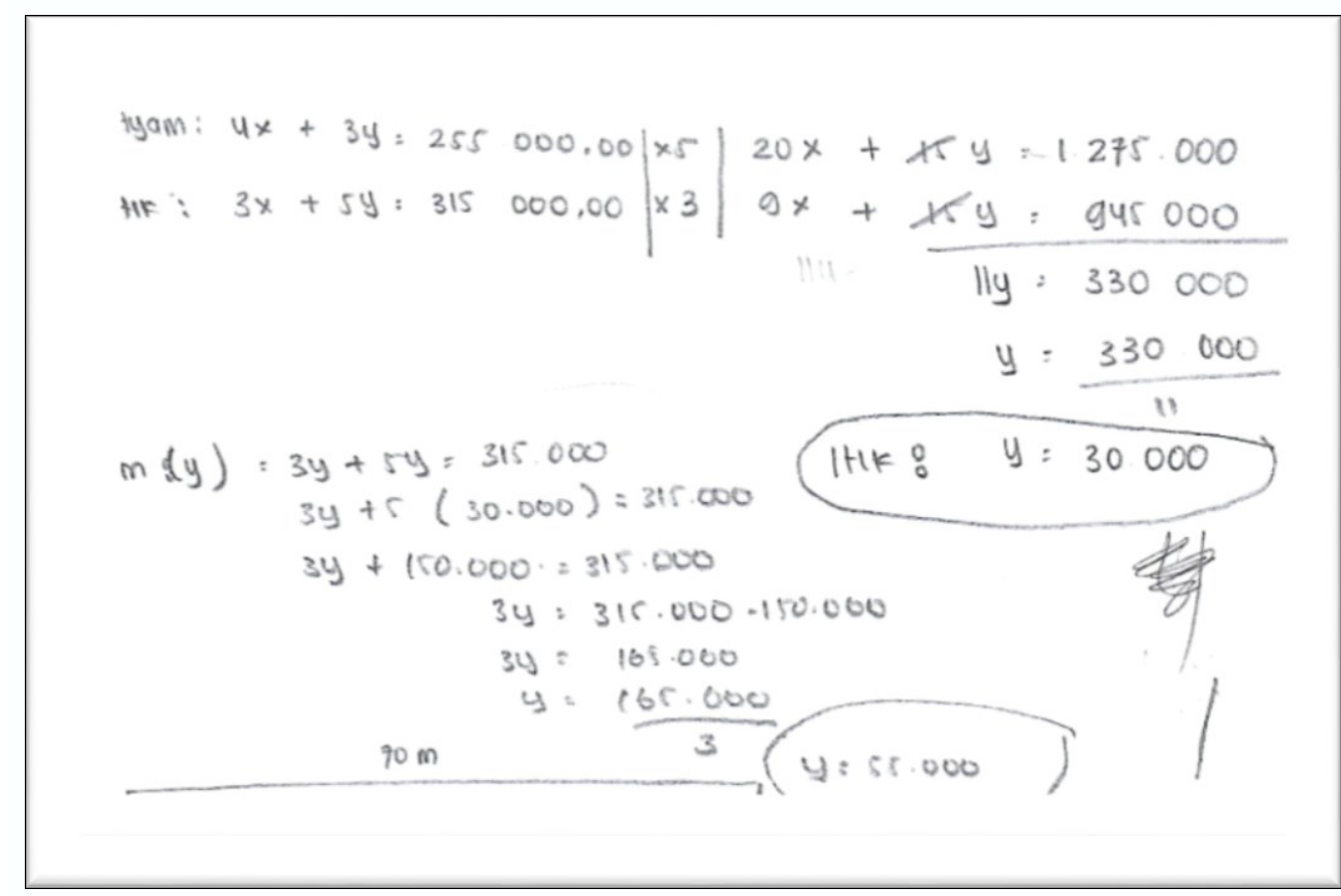

Gambar 2. Hasil pekerjaan siswa pada soal nomor dua.

Berdasarkan gambar 2 terlihat siswa sudah melengkapi data dan membuat proses perhitungan. Akan tetapi, siswa tidak mengindentifikasi soal dan tidak memberikan kesimpulan. Dari hal ini kita bisa menarik kesimpulan, bahwa siswa belum bisa mengungkapkan apa yang dimaksud dari soal tersebut.

Salah satu hasil pekerjaan siswa yang kurang tepat pada soal nomor tiga dengan indikator drawing disajikan pada gambar 3.

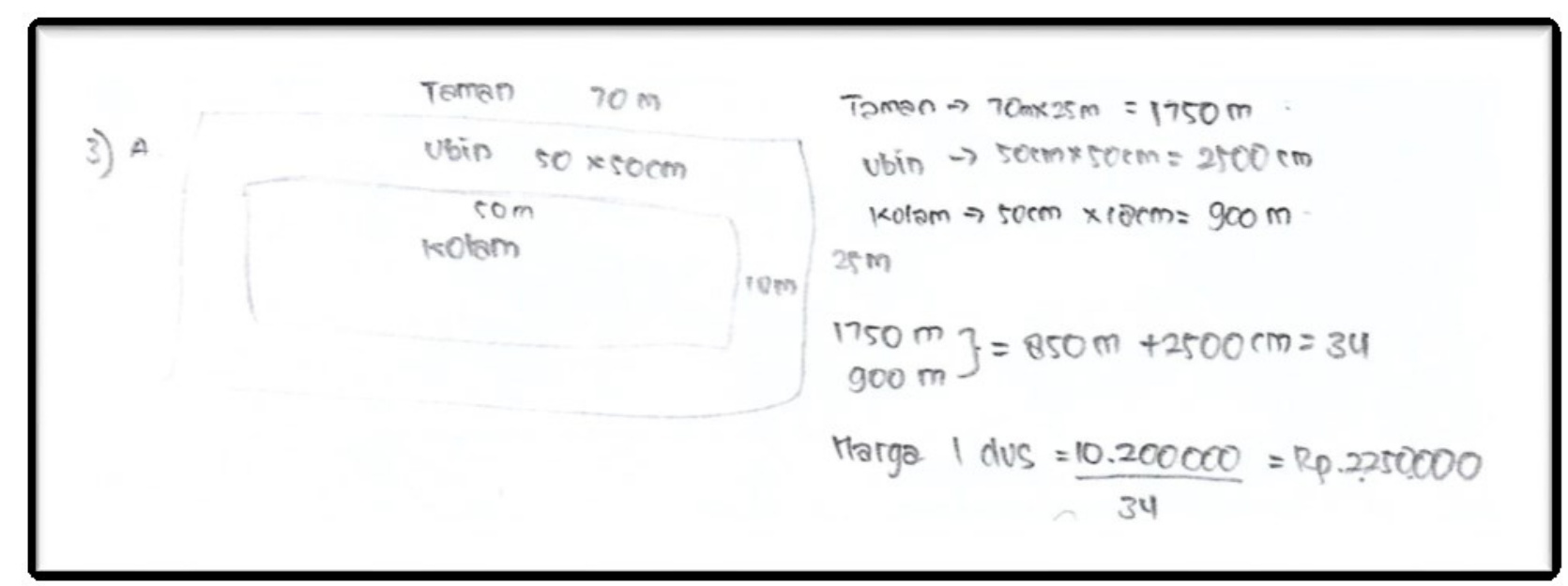

Gambar 3. Hasil pekerjaan siswa pada soal nomor tiga. 
Berdasarkan gambar 3 terlihat siswa sudah melengkapi data namun tidak sempurna dan membuat gambar yang dimaksud pada soal. Akan tetapi, siswa tidak memberikan kesimpulan. Dari hal ini kita bisa menarik kesimpulan, bahwa siswa belum bisa mekuapkan ide dalam bentuk gambar.

Kesulitan yang dialami oleh siswa dalam kemampuan komunikasi terdapat pada indikator written text. Sehingga kemampuan siswa untuk memeberikan jawaban dengan menggunakan bahasa sendiri dapat ditingkatkan. Untuk menstimulus kemampuan tersebut guru dapat mencoba soal-soal berkemampuan komunikasi. Selain itu, siswa juga mempunyai tingkat kecerobohan yang sangat tinggi. Hal ini terlihat ketika siswa dapat melakukan proses jawaban tetapi salah dalam melakukan perhitungan. Kelemahan ini serupa dengan apa yang diteliti oleh (Putra, Setiawan, Nurdianti, Retta, \& Desi, 2018) menyatakan bahwa tidak semua soal matematika dijawab dengan benar akibat siswa kurang fokus dalam menyelesaikan soal sehingga siswa keliru tanpa mereka sadari. Namun, (Farida, 2015) menyatakan kesalahan siswa dalam menjawab soal terjadi karena salah menafsirkan informasi yang diberikan ke dalam ungkapan matematika.

\section{KESIMPULAN}

Berdasarkan penelitian dan analisis yang telah dilaksanakan, kemampuan komunikasi siswa masih sangat rendah. Pada penelitian ini siswa belum mencapai indikator kemampuan komunikasi khusunya pada indikator witten text. Siswa belum bisa mengungkapkan jawaban dengan bahasa mereka sendiri. Dari hasil analisis angket disimpulkan bahwa tidak ada hubungan yang signifikan antara kemampuan komunikasi dengan resiliensi siswa.

\section{UCAPAN TERIMA KASIH}

Peneliti mengucapkan terima kasih kepada rekan teman seperjuanagan dan dosen, khususnya kepada dosen pembimbing yang telah membantu dalam penyelesaian artiker ini. Begitu juga ucapan terimakasih peneliti sampaikan kepada tim JPMI IKIP Siliwangi Bandung yang telah memberikan kesempatan penulis untuk berkontribusi terhadap publishnya artiker ilmiah ini.

\section{DAFTAR PUSTAKA}

Bachri, B. S. (2010). MEYAKINKAN VALIDITAS DATA MELALUI TRIANGULASI PADA PENELITIAN KUALITATIF. Jurnal Teknologi Pendidikan, 10(1), 46-62.

Departemen Pendidikan Nasional. (2007). Kajian Kebijakan Kurikulum Mata Pelajaran IPA, $699 . \quad$ Retrieved from https://www.google.com/search?q=Kajian+Kebijakan+Kurikulum+Mata+Pelajaran+IPA $\& \mathrm{rlz}=1 \mathrm{C1CHBF}$ enID718ID718\&oq=Kajian+Kebijakan+Kurikulum+Mata+Pelajaran+I PA\&aqs $=$ chrome..69i57.680j0j9\&sourceid $=$ chrome\&ie $=U$ UTF-8

Farida, N. (2015). ANALISIS KESALAHAN SISWA SMP KELAS VIII DALAM MENYELESAIKAN MASALAH SOAL CERITA MATEMATIKA. AKSIOMA Jurnal Program Studi Pendidikan Matematika, 4(2), 42-52.

Hendriana, H., Eti Rohaeti, E., \& Soemarmo, U. (2017). Hard Skills dan Soft Skills Matematik Siswa.

Maryam, M. S., Nurdiawan, R., Hermawan, W., Purwasih, R., \& Rohaeti, E. E. (2018). ANALISIS KEMAMPUAN PENALARAN MATEMATIS DAN MATHEMATICAL RESILIENCE SISWA SMA. Jurnal Apotema. 
Mulyadi, M. (2011). PENELITIAN KUANTITATIF DAN KUALITATIF SERTA PEMIKIRAN DASAR MENGGABUNGKANNYA. Jurnal Studi Komunikasi Dan Media, 15(1), 127-138.

Nopiyani, D., Turmudi, T., \& Prabawanto, S. (2018). Penerapan Pembelajaran Matematika Realistik Berbantuan GeoGebra untuk Meningkatkan Kemampuan Komunikasi Matematis Siswa SMP. Mosharafa: Jurnal Pendidikan Matematika, 5(2), 45-52. Retrieved from http://e-mosharafa.org/index.php/mosharafa/article/view/mv5n2_1/169

Putra, H. D., Setiawan, H., Nurdianti, D., Retta, I., \& Desi, A. (2018). Kemampuan pemahaman matematis siswa smp di bandung barat. Jurnal Pendidikan Matematika, $11(1), 1-12$.

Umar, W. (2012). Membangun Kemampuan Komunikasi Umar, W. (2012). Membangun Kemampuan Komunikasi Matematis dalam Pembelajaran Matematika. Jurnal Infinity, 1(1), 1-9. Retrieved from http:/lejournal.stkipsiliwangi.ac.id/index.php/infinity/article/view/2\%5Cnhttp://e-journal. Jurnal Infinity, 1(1), 1-9. https://doi.org/10.22460/infinity.v1i1.2

Zanthy, L. S. (2018). K Ontribusi R Esiliensi M Atematis Terhadap K Emampuan. Jurnal Mosharafa, 7(1), 85-94. 